Joanna E. Dąbrowska University of Bialystok

\title{
Universal values of Klementyna Tańska-Hoffmanowa's pedagogy
}

\section{WARTOŚCI UNIWERSALNE PEDAGOGII KLEMENTYNY TAŃSKIEJ-HOFFMANOWEJ}

Artykuł przypomina postać Klementyny z Tańskich Hoffmanowej (17981845) - pierwszej pisarki na gruncie polskim, która stworzyła bogaty księgozbiór dla szerokiego grona odbiorców w języku polskim - czasopisma i książki dla dzieci, powieści dla młodzieży i dorosłych. Twórczość Hoffmanowej wzbogacała pamięć małych czytelników wiadomościami z dziejów polskich, wzbudzała umiłowanie ojczystej mowy, poznawanie przeszłości kraju, uwielbienie ważnych postaci ukazanych w szerokim tle historycznym oraz zawierała szereg wskazówek pedagogicznych, kierowanych do rodziców i wychowawców. Pisarka narzuciła opinii publicznej jasno sprecyzowany ideał wychowawczy dla kobiet i przedstawiła odpowiedni dla nich program naukowy. W jej utworach i współczesny Polak znajdzie wartości ponadczasowe: wskazówki prawdziwego patriotyzmu, kult języka i kultury narodowej, znaczenie wychowania rodzinnego i społecznego, a także takie przesłania, jak: miłość, koleżeństwo, szacunek dla rodziców i starszych, wyrozumiałość, oddanie, poświęcenie, ofiarność, uczynność.

Słowa klucze: XIX wiek, Klementyna Tańska-Hoffmanowa, pisarz, pedagogia, patriotyzm.

Exploring the history of the Polish family as an educational environment, I came across the name of Klementyna Hoffmanowa, born 
Tańska (1798-1845) ${ }^{1}$. Intrigued by the achievements of the first woman in our country "making a living by writing", it startled me why she was an obscure figure that was insufficiently researched, described and, above all, "belittled" by the literature so far ${ }^{2}$. Investigating her life and acquiring successive information about her work and accomplishments, the picture of an extraordinary woman, an extremely important writer and pedagogue of her time and, most of all, a highly ethical and righteous person was forming in my mind. Discovering subsequent stories of her private life, literary work and patriotic and charitable activity, I noticed how consistent and natural $\mathrm{K}$. Hoffmanowa was in joining together a practical educational approach with principles embedded in Catholic faith. Although she did not create a pedagogical system, as Jan Hulewicz - a conscientious researcher of women's education in the $19^{\text {th }}$ century - stated, her accomplishments were considerable in her time: she imposed on the public opinion a clearly specified educational ideal for women, presented a quite extensive scientific program, created periodical press and Polish literature for children, and finally, declared a war against a prevalent French language by writing for Polish youth and Polish women in their native language ${ }^{3}$.

\section{The bases of Klementyna Tańska's pedagogical opinions ${ }^{4}$}

Klementyna Tańska has never articulated thoroughly and systematically her opinions on general educational principles, or the purpose

1 The fruit of scientific peregrinations is the publication: J. E. Dąbrowska, Klementyna. Rzecz o Klementynie z Tańskich Hoffmanowej, Białystok 2008, where a wide spectrum of Klementyna Tańska-Hoffmanowa's literary, pedagogical, patriotic and charitable activity has been discussed.

2 Basic biographical information concerning Klementyna Tańska-Hoffmanowa may be found in Estreicher (K. Estreicher (ed.), Bibliografia polska XIX stulecia, Kraków 1972, v. X, pp. 306-321), in Nowy Korbut (Bibliografialiteratury polskiej, Nowy Korbut, Warszawa 1971, v. VI, part 1, pp. 318-331), or in Polski Stownik Biograficzny (Polski Stownik Biograficzny, Ossolineum 1961, v. IX/4, book 43, p. 573-576) but there is lack of comprehensive studies on her life and works. Klementyna Hoffmanowa is not mentioned during history or Polish lessons and only few people know that we can use a numeral "first" to describe her activity in many areas - see: J. E. Dąbrowska, Klementyna..., op. cit., p. 85, 93-94, 109, $250,255-257,263-271$.

3 See: J. Hulewicz, Sprawa wyższego wyksztatcenia kobiet $w$ Polsce $w$ wieku XIX, Kraków 1939, p. 36-37.

4 This issue has been widely discussed in the publication: J. E. Dąbrowska, Klementyna..., op. cit., p. 169-194. Here the most important content has been extracted to refer it to universal values preferred by K. Tańska. 
and means of education, which has already been noticed, inter alia, by a conscientious researcher of her work - Piotr Chmielowski ${ }^{5}$. She presented them "fragmentarily and randomly in her different writings" Tańska's psychology was based on practical observations and slightly old-fashioned literature. Nevertheless, she created a rich book collection for a wide group of readers - magazines and books for children, novels for youngsters and adults. Before her, nobody was writing for them in their native language; only few samples were appearing. Until the times of K. Hoffmanowa, children were either learning from French handbooks or not learning at all, girls in particular ${ }^{7}$. That is why in her works she instigated people's minds towards rational education of youth, fought existing superstitions and disseminated pedagogical theories of European pedagogues she was familiar with. For this reason, her works and all her collected opinions constitute an epoch in the education of the Polish society ${ }^{8}$.

Tańska's pedagogical and ethical notions were based on three powers of "human spirit": a soul, heart and mind (brain) because "true beauty on three things is suspended: a beautiful soul, good and soft heart and flourishing mind. According to this nineteenth century writer, getting it is worth the utmost concentration and endeavor" ${ }^{10}$. In her reflections presented in the first serious work titled Pamiattka

$5 \quad$ See: P. Chmielowski, Klementyna z Tańskich Hoffmanowa. Zarys biograficzno-pedagogiczny, Petersburg 1899, p. 39. Whereas the attempts at specifying K. Tańska's educational ideal were made by J. Hulewicz - see: J. Hulewicz, Sprawa wyższego wyksztatcenia..., op. cit., p. 26-37.

P. Chmielowski, Klementyna z Tańskich Hoffmanowa..., op. cit., p. 39.

$7 \quad$ Klementyna Tańska's home upbringing may serve as an example to observe girls education in the house of Aniela Szymanowska, District Governess. The future writer studied works of the following authors: Zofija Cottin, Jacques Delille, Stéphanie Felicité Genlis of Ducrest de Saint-Aubin, Jean de La Fontaine, Klaudyjusz Franciszek Millot, Karol Rollin and Adela Souza of Filleul, see: K. Hoffmanowa, Notatki. Przez Klementynęz Tańskich Hoffmanowa, Warszawa 1851, pp. 10-11; S. Pruszakowa, Rozrywki dla młodocianego wieku, Warszawa 1856 , v. I, p. 296.

See: J.Nitowski, Klementynaz Tańskich Hoffmanowa, "Przegląd Pedagogiczny" 23 (1898), pp. 407-408.

General outline of K. Tańska's "human spirit powers" has been discussed by Piotr Chmielowski-see: P. Chmielowski, Klementynaz Tańskich Hoffmanowa..., op. cit., pp. 40-43.

10 K. Hoffmanowa, Pamiątka po dobréj matce, [in:] N. Żmichowska (ed.), Dzieła Klementyny z Tańskich Hofmanowéj, Warszawa 1876, v. VIII, p. 337. 
po dobrej matce [Remembering a Good Mother] ${ }^{11}$, she explained that a soul and heart are closely connected, "a soul is a mother of virtues, a heart gave birth to feelings (...) a soul is more perfect, a heart is more voluptuous. (...) There is no firmer charm or greater allurement behind a beautiful soul, a tender and delicate heart than a flourishing mind" 12 .

As a heiress of the Enlightenment Era revering mind and knowledge, $\mathrm{K}$. Tańska reflected the idea of enlightening minds in her works. In O powinnościach kobiet [On Women's Duties] $]^{13}$ she stressed that for her the mind was: "Light, enlightenment or mind because this beautiful power, known by different names, is inherent solely to man, which may well be called a soul of eyes" ${ }^{14}$. Tańska compared the mind to the power capable of transferring a man to another world, another life; that is why she treated man's education as absolute priority. She believed that it was the mind that allowed taking conscious decisions while choosing between an indispensable and unnecessary thing, between good and bad reading; the mind was man's embellishment indeed. How should we develop the mind to be able to use this "greatest human treasure" in the future? Hoffmanowa distinguished two ways thereof: the first one was education through learning whereas the second - through experience. In her opinion, science derived from the mind whereas thanks to science the mind educates, strengthens and hardens itself. That is why "developing it in oneself became an important duty, a necessary self-obligation of every human being capable of thinking"15.

We can find many accurate sentences that complied with the then pedagogical concepts in K. Tańska's observations on the mind's education. She understood a great significance of child's very first impressions and even prescribed paying diligent attention to them in order to skillfully lead but, above all, not diminish them. According to the author, wise and educated parents should be first educators. She believed a good example was an efficient educational means because children are inclined to imitate; it should be used in order

11 The full title o K. Tańska's first work: Pamiatka po dobréy matce czyli ostatnie iéy rady dla córki, Warszawa 1819.

Ibidem, p. 360 and 368.

The work O powinnościach kobiet przez autorkę Karoliny was published already after the writer's death - in 1849. We should remember that these were lectures delivered by $\mathrm{K}$. Hoffmanowa in the Institute of Governesses; in a shortened form titled $O$ moralności dla kobiet they were published in 1841 .

14 K. Hoffmanowa, O powinnościach kobiét, [in:] N. Żmichowska (ed.), Dzieła Klementyny..., op. cit., v. IX, pp. 183-184.

Ibidem, p. 184. 
to achieve certain objectives. She wrote in Listy o wychowaniu [Letters on education $]^{16}$ : "I believe that the whole foundation of truly good education is a good example whereas its most successful fruit is love of virtue and labor. (...) Every child is an empty vessel you can fill in with whatever you like; it is pure glass but easy to contaminate (...). You can find a straightforward way to every child's soul long through their eyes; every child is prone to imitate, therefore their first habits and compulsions grow from what they see (...). Thus a good example is the greatest and most effective education, it will survive and surpass all oral and written rules, it will fill a child's heart, which is waiting, looking forward to and needing an example" ${ }^{17}$. We can clearly see here the influence of John Lock's beliefs. In another place, K. Tańska adds: "I think a child's mind is like empty canvas an artist takes when s/he wants to paint any picture ..."18. Knowing that a child is already learning before they start to talk, K. Tańska advised to engage children in unassisted plays and games. She recommended mothers talks-chats about nature and life and everyday "manual labors" if they want to educate child's mind and talents. She was an advocate of preparing a child to work since their earliest years so that they "were growing up thinking that you cannot live without a job, that work is every man's necessary and indispensable duty"19.

Klementyna Hoffmanowa mostly wrote for children and young girls; thus many of her works have a naive style, easily available to such minds. That is also the reason for so many edifying stories and tales - to protect human beings that were not yet contaminated with despair and evil. That is why so many works were written in Polish to snatch a French book from children's hands and enamor them in "native things" ${ }^{20}$. Raised in deep faith, she demanded it in upbringing,

$16 \quad$ K. Hoffmanowa, Listy o wychowaniu, i różne $w$ tym przedmiocie wyiatki, [in:] Wybór pism Klementyny z Tańskich Hofmanowéy, Wrocław 1833, v. IX.

17

Ibidem, Letter III, p. 10.

Ibidem, Letter IV, p. 17.

Ibidem, Letter VIII, p. 37.

In the second half of the $18^{\text {th }}$ century, consideration of the French civilization somehow became a necessity. The nation awakening to intellectual life had to be provided with the models of learning and neglected education system had to be reformed. In the pursuit of such models, everybody's attention turned to France. However, apart from sensible imitation imposed by the need of the moment, thoughtless imitations followed: French fashions and customs prevailed unconditionally, French became a language spoken at home whereas French love stories became exclusive readings of women and "refined" men. Children, on the other hand, raised by French governesses and teachers (who in masses 
recommending parents to implant religious principles since earliest childhood believing it was a purpose and foundation of education ${ }^{21}$.

She devoted a lot of place in her works to preparation of women to life. Her instructions were addressed at middle class families. Preserving health, hardening physical and moral strengths, enlightening one's mind to become an educated and sapient citizen, a good wife and mother, a reasonable and good housewife $-\mathrm{K}$. Tańska enlisted these tasks when describing women's destiny. Through her writings she imposed on public opinion a clearly crystallized educational ideal of a woman. It was not novel, just on the contrary, it was quite traditional but the consequences she derived from it breathed with innovation. Hoffmanowa skillfully weaved progressiveness with traditionalism and offered new ideas within conservative frames adopting a compromising attitude.

At the beginning of the $19^{\text {th }}$ century, Poland lacked a modern ideal in women's education consistent with the spirit of new pedagogy whereas any mind enlightenment focused on life preparation with willing reference to practical and ready indications of the Commission of Education. Such an attitude to learning "household" activities resulted from the then status of women's issue in our country. As late as in 1824, when attention was paid to women's education, when Fénelon's ${ }^{22}$ treatise on the education of girls was already published, in Listy o wychowaniu K. Tańska had to refute the opinions of those who claimed education was unnecessary for women reminding that women "together with men are destined for immortality in a better life, and in the present one as well (...) they can win good fame among people; that an educated woman is able to use her light to run her household and her life at her best, and she can even be a more virtuous and kinder woman than an unskilled one" ${ }^{23}$.

The program of upbringing and education proposed by K. Tańska to women in Pamiatka, which was subsequently extended in the book O powinnościach kobiet, contained such subjects as history, geography,

arrived in Poland escaping the unrest of the Great Revolution) learned to speak French instead of Polish.

21 For many years, the main events in the life of a future writer were religious ceremonies and rites celebrated by the owners of Izdebno manor where K. Hoffmanowa spent her childhood.

22 It refers to: Fénelon François de Salignac de la Mothe, O wychowaniu mtodzieży ptci żeńskiéy Przez Fénelona Arcybiskupa Kamerackiego. Dzieło po wielu wydaniach, na nowo roku 1818 w Paryżu przedrukowane. Przez Modesta Watta Kosickiego na język polski przełożone, Warszawa - Suwałki 1823. 
natural history, religion, morality, languages as well as female talents and works generally approved of by the society. Moreover, the program included the elements of physics, chemistry and arithmetic. Paying attention to esthetical aspects of girls' education, the writer discussed basic talents: music, drawing, dance, polite conversation, writing letters and beautiful reading aloud, as well as other gifts: calligraphy, singing, handicrafts and authorship. According to the author, talent is a gift - a gift decorating one's mind which should be discovered, developed and maintained by work. Talent becomes a power activating human life being one of the "blessings" provided by comprehensive education; talent contributes to happiness and refinement, it gives a man "his own value" ${ }^{24}$.

The program proposed by $\mathrm{K}$. Tańska became generally acclaimed and was propagated in the instructions recommended by the Commission of Enlightenment and other relevant institutions. In 1826 the Commission of Enlightenment prescribed it to all schools and higher education institutions for girls ${ }^{25}$. From today's point of view, the recommended scope of knowledge may be considered limited but referring it to the time of $\mathrm{K}$. Hoffmanowa - a very significant for the girls who previously did not learn anything at all. It is worth noticing that the requirements the author imposed on women and emphasized in the next novel Krystyna ${ }^{26}$ were not fulfilled even at the end of the $19^{\text {th }}$ century.

\section{Fundamental messages of K. Tańska's pedagogy}

Apart from pedagogical instructions addressed at parents and educators, K. Hoffmanowa's works enriched the memory of young readers with the information about the history of Poland, science and art and aroused fondness of the native language, learning about the past of the country and adoration of historical figures. Writing, for example, Jan Kochanowski $w$ Czarnolesie $e^{27}$, the writer popularized the character of Urszulka in the children's world among the group of your readers for whom Treny were not available yet.

24 See: K. Hoffmanowa, Pamiatka po dobréj matce, op. cit., v. VIII, p. 368-380; K. Hoffmanowa, O powinnościach kobiét, op. cit., v. IX, p. 202-208.

25 K. Tańska's program was published in: Szczegółowa instrukcya względem sposobu dawania nauk po pensyach i szkołach wyższych ptci żeńskiéy, Warszawa 1826. 
It is worth emphasizing here once again that before the time of $\mathrm{K}$. Hoffmanowa children were mainly learning from French books and reading primers or were not learning at all ${ }^{28}$. It was an entirely common phenomenon that many women from upper class were not able to speak fluent and accurate Polish as they neglected our language and all so called "educated" ladies used solely French for correspondence. French was what Latin used to be in the past. French influence reached women's chambers and children's rooms. That is why reviewing Klementyna Hoffmanowa's works today and looking at her life attitude, we can talk not only about attempts but an open fight against foreign language and culture influence in the name of the rights for national culture. Defending a native language, propagating national customs and postulating education in a national language represent the stages of this fight and, at the same time, timeless values propagated by the author. In nearly every K. Tańska's work we read the following words: "Homeland, native land, a Pole, Poles"; we can see the evidence of "the love of homeland" everywhere. All characters and events occurring in her writings are discussed against a wide historical background ${ }^{29}$. The writer demonstrated excellent knowledge of moral life in the 18th century received from still fresh family traditions. In her works she vividly described the reality of the turn of the $18^{\text {th }}$ and $19^{\text {th }}$ centuries as well as earlier epochs (e.g. in the novel about Jan Kochanowski, it was $16^{\text {th }}$ century).

Klementyna Tańska-Hoffmanowa wanted to make both the past and everything and anything connected with the country and people's life dear to young citizens. That is why everywhere, on every occasion, she talked about homely things, collected details about objects and people, conscientiously noted down every information she "succeeded to find in old books, read on a mossy monument or encounter on the pages of a chronicle". Nevertheless, her writings are not only of historical importance. Reading her short stories and tales, we find "noble" and timeless values such as love, joy, respect and sacrifice for another man, tolerance, humbleness and important advice to enjoy every day. In her works she continued and propagated the recommendations of the Commission of National Education and Jędrzej Śniadecki concerning

\footnotetext{
28 See: E. Jerlicz, Klementyna z Tanskich Hoffmanowa. Zarys literacki, "Biblioteka Warszawska" v. IV (1898), p. 387.

$29 \quad$ E.g., discussing the character of Castellan's wife M. Lanckorońska, she wrote about the Bar Confederation - K. Hoffmanowa, Biografie znakomitych Polaków i Polek, [in:] Wybór pism..., op. cit., v. IV, p. 369-371.
} 
physical education advising "strengthening a body by all means"30. In her opinion, "today, almost everything in women's education is limited to trivial talents and futile information; nothing is given to harden their soft hearts, nothing supports their weak minds: yes, everything excites their feelings, awakens and instigates vanity, swings imagination and misleads" 31 . The importance of moral education, that is learning about duties (recommended earlier by the Commission of National Education) is worth emphasizing as $\mathrm{K}$. Hoffmanowa devoted a lot of place to it in all her works. In her opinion, education is to shape a man in such a way as to make him fulfill "obligations of his real destiny" 32 the best as he can. She believed that personality was inherent but did not exclude a possibility of its development through good examples which a child should be provided with in an indefinite number since its earliest years. Thanks to examples provided at a young age and Teologia rodziny persistent work on oneself at an older age, a man can bring himself up. K. Tańska put moral education even above "mind cultivation and exercise" ${ }^{33}$ whereas her ethics remained closely connected with educational concepts. She expressed ethical principles in all her works and collected them separately in two different books: Pamiatka and $O$ powinnościach kobiet. Talking about virtues and vices typical of female sex, she did not go into details whether ethics maybe should be different for women and different for men. She undeniably found some common ground where both ethics met. Although she did not specify precisely this ground, she indicated differences between female and male duties. Unspecified attitude of $\mathrm{K}$. Hoffmanowa to the perception of basic foundations of moral education resulted from the lack of psychological preparation and competent studies on ethics, which she humbly admitted ${ }^{34}$.

The author of Powinności built a structure of her concept of education upon traditional foundation (based on religion). Speaking mostly to a heart and referring to religious feelings of her female readers, she gave practical rules. She did not try to prove her principles

Recommendations concerning physical education: Ustawy Komissyi Edukacyi Narodowej dla stanu akademickiego i na szkoty w krajach Rzeczypospolitej przepisane, Warszawa 1783, R. XXV Edukacja fizyczna; J. Śniadecki, O fizycznym wychowaniu dzieci, "Dziennik Wileński" 5-7 (1805).

$31 \quad$ K. Hoffmanowa, O powinnościach kobiét, op. cit., v. IX, p. 148.

$32 \quad$ Ibidem, p. 52.

$33 \quad$ Ibidem, p. 7.

34 See: ibidem. 
scientifically (she was afraid of fanaticism and bigotry ${ }^{35}$ ) but she only rhetorically amplified their importance both in Amelia matka ${ }^{36}$ and the treatise $O$ powinnościach. Entire content of her moral teaching is included in the advice: "Know and fulfill your duties"37.

\section{The importance of K. Tańska's pedagogy}

In the epoch when it was very common for girls residing in nobility mansions not to be able to write and when education of girls from upper classes was merely limited to superficial cultivation of "talents" and learning French, Klementyna Tańska-Hoffmanowa declared a principle according to which a woman should take advantage of "the treasures of the light" and work on educating their minds. For this reason, even though she has not made any progress in pedagogy, today she has been appointed a "precursor of Polish pedagogy" ${ }^{38}$.

$\mathrm{K}$. Tańska was not specially gifted in theorizing but she could speak to the public that was "mainly composed of the minds of average abilities, made up of warm yet not volcanic hearts that followed her advice and found it the most appropriate and suitable for their society. They neither desired independence, nor needed comprehensive or profound knowledge; they satisfied feelings very easily" 39 .

In the first half of the 19 th century, each new work that was released aroused discussion and drew people's attention because it was rare, not to mention the entire book written by a young woman (Pamiatka po dobrej matce ${ }^{40}$ ) or a cyclical periodical (Rozrywki dla Dzieci $\left.i^{41}\right)$. For a long time, Pamiatka was a methodology handbook used in girls' education and served their enlightenment within the scope of women's duties and destiny. The author repeated the principles stated therein

35

K. Hoffmanowa cared about "pure" religion: true, thorough and moderate piety - see: Pamiętniki Klementyny z Tańskich Hoffmanowey, [in:] Pisma pośmiertne Klementyny $z$ Tańskich Hoffmanowey, Berlin 1949, v. II, p. 112.

K. Hoffmanowa, Amelia Matka. Dzieło za dalszy ciag Pamiatki po dobrej Matce stużyć mogące przez tęż sama Autorkę, Warszawa 1822-1824.

K. Hoffmanowa, O powinnościach kobiét, op. cit., v. IX, p. 13.

The term used by a contemporary historian of literature and literary critic Grażyna Borkowska - G. Borkowska, Cudzoziemki. Studia o polskiej prozie kobiecej, Warszawa 1996, p. 57.

P. Chmielowski, Klementyna z Tańskich Hofmanowa..., op. cit., p. 56.

See: footnote 10 .

"Rozrywki dla Dzieci wydawane przez Autorkę Pamiątki po dobrej Matce" were published in 1824-1828. 
thirty years later in Powinności. She designated them then for mature women and she treated them more seriously and comprehensively. $\mathrm{K}$. Hoffmanowa believed that increase of women's intellectual level was the most efficient remedy "for fickleness, carelessness, pursuit of trivia, outfits and expensive clothes" $"$. Moreover, in Powinności, this "ultra-conservative" 43 , as she was considered to be by some, demonstrated a considerable progress in the matter of girls' upbringing and education. She expressed quite revolutionary sentences for Poles at that time: "Women's education generally lacks order, lacks planning, lacks completeness; women are not taught classical languages [Latin and Greek]or serious and creative skills: but their entire wisdom is based on picking up the prime of science as fast as possible, that is to comprehend the easiest things, which shine and catch the eye. (...) they taste a little here, a little there, and explore nothing. (...) women can and should be permitted to the light" ${ }^{44}$.

Summing up K. Tańska's writings in the field of pedagogy, Jan Hulewicz said that "writing and creating at the time when women's education lied in total fallow, K. Tańska could not create any system of scientific pedagogy" 45 . Nevertheless, certain educational canon indicated by her caused that further actions in the area of women's education referred to her work: they were its continuation or a starting point for the opposition ${ }^{46}$. Aleksander Świętochowski's critical opinion should be reminded here: he called her educational code a "crippled program" forgetting that it was in force until his time. In his speech, this critic called $\mathrm{K}$. Hofmannowa a mother, lawmaker and even patron of female education. He also admitted that even though she did not create an original system of education, her huge achievement was

42 E. Jerlicz, Klementyna z Tańskich Hoffmanowa..., op. cit., p. 395.

43 See: ibidem.

$44 \quad$ K. Hoffmanowa, O powinnościach kobiét, op. cit., v. IX, p. 186-187.

45 J. Hulewicz, Sprawa wyższego wyksztatcenia..., op. cit., p. 36.

$46 \quad$ Opinions expressed by K. Hoffmanowa were up-to-date for many years whereas pedagogical content contained in her works constituted the basis of girl's education for a long time. As Mikołaj Pietrowicz Awienarius, a school inspector in Aleksandryjsko-Maryjski Institute for Girls in Warsaw in 1864, stated that even after the lapse of over thirty years, famous "moral education" proved to be "not more or less but reading ultra-patriotic books of a renowned Polish writer K. Tańska” - N. Awienarius, Warszawskija wospominanija, „Istorikolitieraturnyj żurnal” R. 24 (1904), p. 432. 
gathering, systemizing and elevating to dignity moral rights, traditional thoughts and advice ${ }^{47}$.

An excellent description of $\mathrm{K}$. Tańska's entire pedagogy may be her simple and modest words when she formulated pedagogical creed upon Bronisław Trentowski's request: "my principles, purposes and pursuits have always been and are so simple. Only two desires stimulated my writing: to make good Poles and true women from our females" $"$.

Klementyna Tańska-Hoffmanowa stood far away from emancipation or revolutionism, she was neither a social nor moral reformer. She believed that morality must be based on religion, however, she proposed neither bigotry nor asceticism; she told girls about the duties of future wives and mothers without prudery. At the time when most often parents' or guardians' will decided about marriage, she advised following one's heart and common sense when choosing a husband. She condemned pre-calculated marriages. She warned that personal values should prevail over beauty. Her advice on health preservation was not devoid of common sense. In contacts with people she advised modesty, naturalness and kindness to others. She also did not fail to mention women's vices.

Despite general progress made in the $19^{\text {th }}$ century, as Eleonora Jerlicz stated, K. Hoffmanowa's advice was still considered up-to-date and valuable for vast majority of women in $1898^{49}$.

Today, K. Tańska's works are covered with dust but maybe it is worthwhile reading them again. Referring to the national literature and mentioning names and works of the most outstanding writers we forget authors of a "lower rank" whose achievements many a time contain true literary jewels, by all means deserving studies and popularization.

Klementyna Hoffmanowa deserves attention of not only literature connoisseurs. We should attract adult mature readers as well as a little younger generation to her person and achievements. Every Pole may find in her works instructions for true patriotism, cult of national language and culture, the importance of family and social education, and, most of all, such universal values as love, companionship, respect to parents and elders, tolerance, commitment, sacrifice, generosity and helpfulness. Perhaps in the contemporary world of Pokemony and

\footnotetext{
47 See:A. Świętochowski, Ośredniem wyksztatceniu kobiet,"Przegląd Tygodniowy" 15, 19 (1873), p. 115, 147.

J. Hulewicz, Sprawa wyższego wyksztatcenia..., op. cit., p. 36.

See: E. Jerlicz, Klementyna z Tańskich Hoffmanowa..., op. cit., p. 391-395.
} 
ruthless computer games, we should return to simply "human" values the preservation of which the "founder of the library for Polish youth" 50 was fighting for and invariably preached in her works.

Key words: $19^{\text {th }}$ century, Klementyna Tańska-Hoffmanowa, a writer, pedagogy, patriotism.

\section{Bibliography:}

1. Awienarius N., Warszawskija wospominanija, „Istoriko-litieraturnyj żurnal" R. 24 (1904).

2. Bibliografia literatury polskiej, Nowy Korbut, Warszawa 1971, v. VI.

3. Borkowska G., Cudzoziemki. Studia o polskiej prozie kobiecej, Warszawa 1996.

4. Chmielowski P., Klementyna $z$ Tańskich Hoffmanowa. Zarys biograficznopedagogiczny, Petersburg 1899.

5. Dąbrowska J. E., Klementyna. Rzecz o Klementynie z Tańskich Hoffmanowej, Białystok 2008.

6. Estreicher K. (ed.), Bibliografia polska XIX stulecia, Kraków 1972, v. X.

7. Fénelon François de Salignac de la Mothe, O wychowaniu młodzieży ptci żeńskiéy Przez Fénelona Arcybiskupa Kamerackiego. Dzieło po wielu wydaniach, na nowo roku 1818 w Paryżu przedrukowane. Przez Modesta Watta Kosickiego na język polski przetożone, Warszawa - Suwałki 1823.

8. Hoffmanowa K., Amelia Matka. Dzieło za dalszy ciagg Pamiątki po dobrej Matce stużyć mogące przez tę̇̇ sama Autorkę, Warszawa 1822-1824.

9. Hoffmanowa K., Biografie znakomitych Polaków i Polek, [in:] Wybór pism Klementyny z Tanskich Hofmanowéy, Wrocław 1833, v. IV.

10. Hoffmanowa K., Jan Kochanowski w Czarnolesie. Obrazy z końca szesnastego wieku przez Autorkę Karoliny, Lipsk 1842.

11. Hoffmanowa K., Krystyna przez Autorkę Karoliny, Lipsk 1841.

12. Hoffmanowa K., Listy o wychowaniu, i różne $w$ tym przedmiocie wyiattki, [in:] Wybór pism Klementyny z Tanskich Hofmanowéy, Wrocław 1833, v. IX.

13. Hoffmanowa K., Notatki. Przez Klementynę z Tańskich Hoffmanowa, Warszawa 1851.

14. Hoffmanowa K., O powinnościach kobiét, [in:] N. Żmichowska (ed.), Dzieła Klementyny z Tanskich Hofmanowéj, Warszawa 1876, v. IX.

15. Hoffmanowa K., Pamiątka po dobréj matce, [in:] N. Żmichowska (ed.), Dzieła Klementyny z Tanskich Hofmanowéj, Warszawa 1876, v. VIII.

16. Hoffmanowa K., Pamiętniki Klementyny z Tańskich Hoffmanowey, [in:] Pisma pośmiertne Klementyny z Tańskich Hoffmanowey, Berlin 1949, v. II.

17. Hulewicz J., Sprawa wyższego wyksztatcenia kobiet $w$ Polsce $w$ wieku XIX, Kraków 1939.

18. Jerlicz E., Klementyna $z$ Tańskich Hoffmanowa. Zarys literacki, "Biblioteka Warszawska" v. IV (1898). 
19. Nitowski J., Klementyna z Tańskich Hoffmanowa, "Przegląd Pedagogiczny" 23 (1898).

20. Polski Stownik Biograficzny, Ossolineum 1961.

21. Pruszakowa S., Rozrywki dla mtodocianego wieku, Warszawa 1856.

22. Śleczkowska M., Klementyna z Tańskich Hoffmanowa, Kraków 1898, v. I.

23. Śniadecki J., O fizycznym wychowaniu dzieci, "Dziennik Wileński" 5-7 (1805).

24. Świętochowski A., O średniem wyksztatceniu kobiet, "Przegląd Tygodniowy" 15, 19 (1873).

25. Tańska K., Pamiatka po dobréy matce czyli ostatnie iéy rady dla córki, Warszawa 1819.

26. Tańska K., Szczegółowa instrukcya względem sposobu dawania nauk po pensyach i szkołach wyższych ptci żeńskiéy, Warszawa 1826.

27. Ustawy Komissyi Edukacyi Narodowej dla stanu akademickiego i na szkoty w krajach Rzeczypospolitej przepisane, Warszawa 1783. 